\title{
Insects associated with green gram (Vigna radiata L.) in Langtang, Southern Guinea Savanna of Nigeria
}

\author{
NDAM Oliver Nimchang ${ }^{1}$, DASER Vincent Panmut ${ }^{2}$ and OMBUGADU Akwashiki ${ }^{3 \star}$ \\ ${ }^{1}$ Plateau State College of Agriculture, P.M.B. 001, Garkawa, Plateau State, Nigeria. \\ 2Boys' Secondary School, Gindiri, P.M.B.2127, Jos, Plateau State, Nigeria. \\ ${ }^{3}$ Department of Zoology, Faculty of Science, P.M.B. 146, Federal University Lafia, Nasarawa State, Nigeria. \\ *Corresponding author: akwash24@gmail.com. Tel: +234 8034867540.
}

Copyright @ 2018 Ndam et al. This article remains permanently open access under the terms of the Creative Commons Attribution License 4.0, which permits unrestricted use, distribution, and reproduction in any medium, provided the original work is properly cited.

Received 7th November, 2018; Accepted 12th December, 2018

\begin{abstract}
Green gram is a 'wonder' or 'super' food with health benefits. It is one of the shortest growth duration grain legumes that are also suitable as catch crops. Leguminous crops generally attract insect pests because of their high nutritive value. Hence, a survey of insects associated with green gram (Vigna radiata L.) treated with insecticide and fungicide was conducted in Kwanpe, a suburb of Langtang in Plateau State, Nigeria from July to September during the 2014 cropping season. Four treatments of dimethoate (an insecticide) were applied (at $0,300,500$, and $700 \mathrm{~g}$ a.i./ha) in four replicates arranged in a Randomized Complete Block Design. A total of 40 insect species belonging to 4 orders and 8 families were captured. Species known to be pests in other legume crops encountered were 22. There were few predatory species. There were no statistical differences in pest species populations in treated and untreated green gram plots. It is recommended that there is no need to engage synthetic chemicals in the production of green gram in this locality. Regular insect surveillance is however required as a monitor for pest species populations in order to set economic threshold levels in this Southern Guinea Savanna ecological zone for the highly valued crop.
\end{abstract}

Keywords: Vigna radiata, crop damage, insect checklist, pest control.

\section{INTRODUCTION}

Majority of people in the developing countries are engaged in agricultural activities but with low productivity (Kumar, 1991). Grain legumes are of considerable importance in Nigeria because they provide a major source of protein in human and animal nutrition. They are of particular advantage in subsistence and mixed farming because they can grow on nitrogen-deficient soils (Schroth et al., 2000; Rao et al. 2004). They are well fitted to agro-forestry cropping systems (Rao et al., 2000). Green gram grows best at an altitude of 0 to $1600 \mathrm{~m}$ above sea level and under warm climatic conditions (temperature range of 28 to $30^{\circ} \mathrm{C}$ ). They are well adapted to soils that are red sandy loam, but also do reasonably well on those that are not too exhausted though sandy. Green grams are not tolerant to wet, poorly drained soils. They are drought tolerant and will give reasonable yields with as little as $650 \mathrm{~mm}$ of yearly rainfall. Heavy rainfall results in increased vegetative growth with reduced pod setting and development (CBS Kenya Govt, 2003; URT, 2003). Additionally, it is adapted to poor soils because it forms associations with mychorrhiza (Kasiamdari et al., 2002) and is a relay crop, hence plays an important role in environmental conservation and food security, respectively (Machocho et al., 2012).

However, production of green gram is constrained by diseases, pest infestations, unsuitable varieties and inappropriate agronomic practices (Rao et al., 2000). These practices, particularly pest and disease control, entail the use of industrial chemicals. The practices are expensive, pose health hazards and are environmentally undesirable. Besides, the chemicals are not popular among the resource poor farmers who are also the main producers and consumers of the legume (Machocho et al., 2012). 
The major constraint to current legume yields in India and some parts of East Africa is pest infestation, either as vectors of diseases or destroyers of seedlings, foliage or fruiting bodies in India (Davies and Lateef, 1975; Saxena, 1978; Seif et al., 2001). Incidences of diseases and pests are comparatively low during the dry months when the crop escapes rain damage. According to Davies and Lateef (1975), for instance, pests account for 20 to $25 \%$ loss of green gram yield in India. It has been established that in order to achieve high crop yields, even with the potentially high yielding varieties grown in the United States of America, plants must be adequately protected from insect pests (Cook, 1986).

Green gram is one of the shortest growth duration grain legumes that are also suitable as catch crops (Seif et al., 2001; Emmanuel et al., 2017). It arrests the hunger which peasant farmers often experience, where it is grown, before many other crops mature (Purseglove, 2003; Anon, 2007). While the world production of $V$. radiata is concentrated in India and China, records of production on the African continent are in Kenya and Tanzania. In Nigeria, the crop is highly restricted to Langtang-North and Wase Local Government Areas of Plateau State and said to have been introduced by the white missionaries of the Sudan United Mission (SUM) in 1908/1909 (Lere, 1996). The crop was a readily available source of vegetable eaten with boiled rice. For over a centenary now, farmers in the locality have not stopped producing and consuming the crop on small scale. Production is however gradually gaining commercial quantity (Seif et al., 2001).

The crop is referred to as a 'wonder' or 'super' food (Mogotsi, 2006). The health benefits of the beans are increasingly exploding with more research on the crop. Weight loss is achieved because the beans are low in calories and rich in fibre (Minh, 2014). The insoluble fibres present in the seeds help to keep the digestive system healthy and reduce the problem of constipation. Eating a small cup of green gram bean soup therefore gives the feeling of fullness. It therefore helps to curb hunger pangs and bring body weight to healthy levels. Regular consumption of the seeds helps to reduce unhealthy cravings for sweet artificial foods thus regulate blood sugar level (Arya, 2014). Its high potassium content lowers blood pressure by counteracting the effect of sodium (Mogotsi, 2006; Arya, 2014).

It has an awesome and acceptable taste no matter the preparation. In India, the bean is cooked for sick people who may have lost appetite for food. Its healing properties have therefore been found to be gaining undisputable popularity. The potassium and magnesium components of the seeds are important for a healthy heart, while its folic acid is important for pregnant women and women of child bearing age (Arya, 2014). Other minerals present in the crop include zinc, iron and phosphorus. Vitamins are essential to maintain good health and prevent diseases. Green mung bean sprouts are rich in Vitamin $\mathrm{C}$ which improves the immune system and keeps the common fever, sore throat and cold away. Eating green gram thus gives the benefit of fruit consumption (Minh, 2014; Raman, 2018; Umata, 2018).

A host of benefits of consuming green gram was outlined by beneficiaries as: it helps to reduce weight and fightobesity, lowers blood pressure, controls cholesterol and heart disease risk, helps fight cancer, boosts immunity and protects against infections, improves skin health and possesses anti-toxic properties (Arya, 2014). In China and India, green gram beans are frequently recommended to detoxify the blood and get rid of chronic illnesses. It is an anti-inflammatory food and helps to heal the body through improved body metabolism (Tang et al., 2014).

Leguminous crops generally attract insect pests because of their high nutritive value (Mogotsi, 2006). Their protein and vitamin content are a source of nourishment to insects, just as humans. In Uganda both yield and seed quality are significantly reduced (ranging from $80-100 \%$ ) by damage due to insects, if no control is undertaken (Emmanuel et al., 2017). Adamu et al. (2001) recorded up to $92 \%$ seed losses in green gram due to damage by the pod weevil, Piezotrachelus varius in the northern guinea savanna zone of Nigeria. Whiteflies (Bemisia tabaci and Aleurodicus dispersus), blister beetles (Mylabris species) and stink bug (Nezara viridula) were also found in the area.

Since green gram have economic, nutritive and medicinal values, however there is paucity of information on insect fauna of the plant. Hence, the aim of the study was to survey insects that are associated with the crop in its presently well adopted area of production in relation to treatments with dimethoate insecticide and fungicide. It is hoped that the findings in this experiment would provide useful information to further study the insect fauna of the crop as its production is fast increasing.

\section{MATERIALS AND METHODS}

The study was carried conducted in Kwanpe, a suburb of Langtang (latitude $9^{\circ} 08^{\prime} \mathrm{N}$ : longitude $9^{\circ} 47^{\prime} \mathrm{E}$ ) in Plateau State, Nigeria from July to September during the 2014 cropping season. A total land area of $320 \mathrm{~m}^{2}(20 \mathrm{~m} \times 16$ $\mathrm{m})$ was ploughed and harrowed. Compound fertilizer $\left(\mathrm{N}_{15}\right.$ $\mathrm{P}_{15} \mathrm{~K}_{15}$ ), was applied at the rate of $200 \mathrm{mkg} / \mathrm{ha}$, according to the common practice of green gram farmers, before ridges of $100 \mathrm{~cm}$ apart were made. Four blocks separated by $1 \mathrm{~m}$ alleys and consisting of four plots $(4 \mathrm{~cm} \times 3 \mathrm{~cm})$ which were each separated by a $1 \mathrm{~m}$ alley to minimize inter-plot interference were provided.

Four treatments, consisting of three levels of insecticide application and a control, were replicated four times. These were arranged in a Randomized Complete Block Design (RCBD). Dimethoate, an organophosphate insecticide available as Kartodim $315 \mathrm{EC}$, was applied at the rate of $(0,300 \mathrm{~g}, 500$ and $700 \mathrm{~g}$ a.i./ha). A broad spectrum preventive fungicide for the control of foliar fungal diseases, copper oxychloride, available as Red 
Force was tank-mixed at the rate of $800 \mathrm{~g}$ a.i./ha with dimethoate and sprayed using a knapsack sprayer. Planting was done in the last week of July 2014. Pesticides application commenced two weeks after planting (WAP) (i.e. 2nd week of August 2014) and continued at weekly intervals thereafter till week 8 . Control plots received water spray only. Spraying time was maintained at 9.00 hours each time.

\section{Sampling of Insect fauna}

The Sweep Net: Insects were collected from 9.00 to 11.00 hours using a sweep net of $18 \mathrm{~cm}$ diameter, $28 \mathrm{~cm}$ deep, mesh size of about $20 \mathrm{~mm}$ and a handle $29 \mathrm{~cm}$ long. Five swings along $3 \mathrm{~m}$-row of crop canopy on one of two middle rows in each plot constituted one sweep, according to the method of Paulson (2005). After each sweep-net sampling, net was emptied into a killing jar. Insect specimens were immediately transferred to labeled transparent specimen bottles containing $70 \%$ alcohol for preservation. They were conveyed to the laboratory for identification.

Tagged Plants: Five plants per plot were randomly tagged for weekly in situ observation. Tagged plants were closely observed for sedentary insects same day with sweep net sampling. With the aid of flexible forceps any insect observed was picked, killed and preserved in $70 \%$ alcohol. Collections were conveyed to the laboratory for identification.

\section{Assessment of growth and yield components of the crop}

Crop growth and yield parameters assessed were; number of leaves per plant per week, number of peduncles per plant, number of days to first flower, number of days to $50 \%$ flowering, number of pods per plant, number of insect-damaged seeds per plant,100 seed weight and grain yield (Dike, 1997).

Insect-damaged seeds were recorded by observing insect exit holes on seeds or scarified seed coat or when the germ of the seed was eaten by insects. One hundred seeds picked randomly from the harvested pods of two middle rows of each plot were weighed. Grain yield was measured by bulking pods from two middle rows of each plot, threshing and then weighing them (Dike, 1997).

\section{Insect identification}

Insects collected by both sweep net and hand-picking from tagged plants were identified to species level using morphological characteristics by comparing with preserved specimens at the Insect Museum of the Ahmadu Bello University, Samaru, Zaria. Collections at the Insect Museum had been carefully identified using standard keys which include Borror and White (1970), Skaife (1979), Castner (2000) and Shattuck (2000).

\section{Statistical analysis}

Data obtained was analyzed using R-Console Software version 3.2.2. Pearson's Chi-squared test was used to compare the abundance of insects in relation to treatments on Vigna radiata. Also, the proportion of number of days to flowering, number of days to $50 \%$ flowering, number of pods per plant, weight of 100 seeds, number of insectdamaged seeds and as well as the mean grain yield in relation to treatments on Vigna radiata were compared using Chi-square. P-values $<0.05$ were considered statistically significant.

\section{RESULTS}

\section{Composition of insects associated with green gram}

Tables 1 and 2 show the number of insect species captured in this experiment, listed according to their perceived roles on the crop. Only pest species are shown in Table 1 where 5 insect orders were present. Hemiptera and Coleoptera had 11 and 8 species, respectively. Two species of Orthoptera, one of Homoptera and one of Diptera were recorded.

Table 2 shows the insect orders with predatory and parasitoid species. They included Hymenoptera (4 species), Coleoptera (5 species), Dictyoptera (2 species), Heteroptera (2 species each) and Diptera (2 species). Two species; Lebialate plagiata (Coleoptera: Carabidae) and Cardiophorus hoploderus (Coleoptera: Elateridae) could not be grouped with certainty.

Table 3 shows the overall relative abundance of species. The most abundant were Mirperus jaculus and Monolepta nigeriae, constituting 13.71 and $13.19 \%$ of the total insect population captured, respectively. Estcourtiana bifasciata and Chilomenes sulphurea closely followed in abundance at 12.09 and $9.34 \%$, respectively.

The number of insects caught was highest (11) in control followed by $300 \mathrm{~g}$ and $500 \mathrm{~g}$ dimethoate treatments in which both had 10 while the $700 \mathrm{~g}$ had the least 9 as shown in Table 4. However, there was no significant difference $\left(\chi^{2}\right.$ $=0.2, \mathrm{df}=3, \mathrm{P}=0.9776)$ in the number of insects caught among the treatments.

Table 5 shows the abundance of insect orders in descending sequence. The most abundant groups were Coleoptera and Hemiptera. Relative abundance of insects according to families is shown in Table 6. Chrysomelid beetles constituted $35.6 \%$ of the total captured insects.

\section{Plant growth and yield parameters}

Figure 1 shows the number of leaves per plant for 8 weeks. The maximum and minimum leaf counts were 51 and 47 for the control and dimethoate at $500 \mathrm{~g}$ a.i./ha plots, respectively. These indicated there were no appreciable differences $\left(\chi^{2}=0.20408\right.$, df $\left.=3, P=0.9769\right)$ in leaf 
Table 1. Insect pests associated with Vigna radiataat Langtang, Plateau State, Nigeria

\begin{tabular}{ll}
\hline Order/Name of Insect & Family \\
\hline Coleoptera & \\
Monolepta nigeriae Bryant. & Chrysomelidae \\
Monolepta gossypiperda Bryant. & Chrysomelidae \\
Monolepta kraatzi Jac & Chrysomelidae \\
Estcourtiana bifasciata Jac & Chrysomelidae \\
Cheilomenes sulphurea & Coccinellidae \\
Lema tibialis Casteln. & Chrysomelidae \\
Aulacophora africana Weise. & Chrysomelidae \\
Nisotra dilectra Dalm. & Chrysomelidae \\
& \\
Hemiptera & \\
Lygaeus rivularis Germ. & Lygaeidae \\
Aspavia acumianta Mont. & Alydidae \\
Nezara viridula F. & Pentatomidae \\
Aethemenes chloris Westw. & Pentatomidae \\
Poophilus costalis Walker. & Pentatomidae \\
Clavigrallato mentosicolis Stal & Cercopidae \\
Anoplocnemis curvipes Fabr. & Coreidae \\
Agonoscelis versicolar F. & Pentatomidae \\
Mirperus torridus Westw. & Alydidae \\
Halydicoris species & Pentatomidae \\
Phorticus flavus Stal. & Nabidae \\
Locris rubens Erichson & Cercopidae \\
Orthoptera & \\
Tylopsis irregularis Karsch. & Tettigononiidae \\
Melanostictus melanostictus Schaun. & Acrididae \\
Diptera & \\
Tricyclea species Casteln. & Calliphoridae \\
\hline
\end{tabular}

production due to insecticide application.

It took between 35 and 39 days for the first flower to appear in all the treatments. There was no significant difference $\left(\chi^{2}=0.2349, \mathrm{df}=3, \mathrm{P}=0.9718\right)$ in the number of days for the first flower to appear between treatments (Table 7). Similarly, there was no significant difference $\left(\chi^{2}\right.$ $=0.47191, \mathrm{df}=3, \mathrm{P}=0.925)$ between treatments in the number of days (41 to 47 days) it took to obtain $50 \%$ flowering (Table 8).

Figure 2 is a record of the number of peduncles per plant over time. Up to15 peduncles per plant was recorded and in plots treated with dimethoate at $500 \mathrm{~g}$ a.i./ha while the least number of peduncles (average of 13) was in plots treated with insecticide at $300 \mathrm{~g}$ a.i./ha. However, the number of peduncles among treatments in relation to each observed week showed no significant difference (Week 4: $\chi^{2}=0.4, \mathrm{df}=3, \mathrm{P}=0.9402$; Week $5: \chi^{2}=0.14286, \mathrm{df}=3$, $\mathrm{P}=0.9862$; Week 6: $\chi^{2}=0.28205, \mathrm{df}=3, \mathrm{P}=0.9634$; Week 7: $\chi^{2}=0.14286, \mathrm{df}=3, \mathrm{P}=0.9862$ ).
The number of pods per plant (Table 9) ranged from 72 to 79 , the lowest being in the control plot and the highest was in dimethoate plot treated with $500 \mathrm{~g}$ a.i./ha. However, the number of pods per plant across treatments showed no significant difference $\left(\chi^{2}=0.39474, d f=3, P=0.9413\right)$.

\section{Effect of insect pest damage on yield of Vigna radiata}

Figure 3 compared the number of insect-damaged and undamaged seeds between treated and untreated plots of $V$. radiata. The number of damaged seeds in all cases was negligible. There was no significant difference in the number of insect-damaged seeds between treatments on V. radiata $\left(\chi^{2}=1.0886, \mathrm{df}=3, \mathrm{P}=0.7819\right)$.

Each of the treatments had same weight $(5 \mathrm{~g})$ for 100 seeds. Grain yield ranged between 0.0015 and $0.0017 \mathrm{t} / \mathrm{ha}$ (Table 10) and were not significantly different $\left(\chi^{2}=\right.$ $0.00001746, d f=3, P=1$ ) across treatments. 
Table 2. Predators and parasitoid associated with Vigna radiata in Langtang.

\begin{tabular}{lll}
\hline Feeding Guild & Name of Insect & Family \\
\hline \multirow{3}{*}{$\begin{array}{l}\text { Predator } \\
\text { Parasitoid }\end{array}$} & Coleoptera & Staphylinidae \\
Predator & Lebia malanura Dej & Carabidae \\
Predator & Stenidia corrusca Lar. & Carabidae \\
& Pachnoda cordata Dry. & Scarabaeidae \\
& Diplognatha gagatesForst. & Scarabaeidae \\
& Dictyoptera & \\
Predator & Mantis species & Mantidae \\
& Sphodromantis species & Mantidae \\
& Hemiptera & \\
Predator & Rhinocoris segmentarius Germ. & Reduviidae \\
& Rhinocoris tropicus H\&S & Reduviidae \\
& Hymenoptera & \\
& Camponotus sericeus Fab. & Formicidae \\
Predator & Pheidole species & Formicidae \\
& Braunsia analis Kriechb. & Braconidae \\
& Camponotus acvapimensis Mayr. & Formicidae \\
& & \\
& Diptera & Muscidae \\
& Morellia species & Muscidae \\
\hline
\end{tabular}

Table 3. Cumulative relative abundance of insects on Vigna radiata (L.).

\begin{tabular}{lcc}
\hline Insect species & Number & Relative abundance (\%) \\
\hline Mirperus jaculus & 25 & 13.74 \\
Monolepta nigeriae & 23 & 13.19 \\
Estcourtiana bifasciata & 22 & 12.09 \\
Cheilomenes sulphurea & 17 & 9.34 \\
Nezara viridula & 8 & 4.40 \\
Monolepta kraatzi & 8 & 4.40 \\
Lebia melanura & 7 & 3.85 \\
Pheidole species & 6 & 3.30 \\
Anoplecnemis curvipes & 5 & 2.75 \\
Aulacophora africana & 5 & 2.75 \\
Agonoscelis versicolor & 4 & 2.10 \\
Lygaeus rivularis & 3 & 1.65 \\
Mirperus torridus & 3 & 1.65 \\
Camponotus sericeus & 3 & 1.65 \\
Musca domestica & 3 & 1.65 \\
Diplognata gagates & 3 & 1.65 \\
Paederus sebaeus & 2 & 1.10 \\
Monolepta gagates & 2 & 1.10 \\
Phorticus flavus & 2 & 1.10 \\
Aethemenes chloris & 2 & 1.10 \\
Cardiophorus hoploderus & 1 & 0.55 \\
Sphodromantis sp. & 1 & 0.55
\end{tabular}


Table 3. Contd.

\begin{tabular}{lcc}
\hline Mantis sp. & 1 & 0.55 \\
Tricyclea sp. & 1 & 0.55 \\
Lema tibialis & 1 & 0.55 \\
Camponotus acvapimensis & 1 & 0.55 \\
Halydicoris species & 1 & 0.55 \\
Clavigralla tomentosicollis & 1 & 0.55 \\
Lebia lateplagiata & 1 & 0.55 \\
Melanastictus melanastictus & 1 & 0.55 \\
Morellia species & 1 & 0.55 \\
Nisotra dilecta & 1 & 0.55 \\
Stenidia corrusca & 1 & 0.55 \\
Tylopsis irregularis & 1 & 0.55 \\
Rhinocaris tropicus & 1 & 0.55 \\
Aspavia acuminata & 1 & 0.55 \\
Poophilus costalis & 1 & 0.55 \\
Locris rubens & 1 & 0.55 \\
Agonocelis species & 1 & 0.55 \\
Pachnoda cordata & 1 & 0.55 \\
Braunsia analis & 1 & 0.55 \\
Rhinocoris segmentarius & 1 & 0.55 \\
Total & 174 & 100 \\
\hline
\end{tabular}

Table 4. Total number of insects per treatment in the experiment

\begin{tabular}{lc}
\hline Dimethoate (g a.i./ha) & Number of insects \\
\hline Control & 11 \\
300 & 10 \\
500 & 10 \\
700 & 9 \\
\hline
\end{tabular}

$\chi^{2}=0.2, d f=3, P=0.9776$.

Table 5. Total abundance of insect orders associated with Vigna radiata L. in Langtang during the 2014 cropping season.

\begin{tabular}{lcc}
\hline Insect order & No. of insects & Percentage \\
\hline Coleoptera & 94 & 54.0 \\
Hemiptera & 61 & 35.0 \\
Hymenoptera & 10 & 5.7 \\
Diptera & 5 & 2.9 \\
Dictyoptera & 2 & 1.2 \\
Orthoptera & 2 & 1.2 \\
Total & 174 & 100 \\
\hline
\end{tabular}

\section{DISCUSSION}

\section{Insect composition and association with green gram}

In all, 40-insect species were identified associated with the crop. This association may have evolved over time as no
Table 6. Relative abundance of insect families associated with Vigna radiata during the study period.

\begin{tabular}{lc}
\hline Family & Percentage \\
\hline Chrysomelidae & 35.6 \\
Alydidae & 16 \\
Coccinellidae & 9.8 \\
Pentatomidae & 9.8 \\
Formicidae & 5.8 \\
Carabidae & 5.3 \\
Coreidae & 3.4 \\
Scarabaeidae & 2.3 \\
Muscidae & 2.3 \\
Lygaeidae & 1.7 \\
Staphylinidae & 1.3 \\
Mantidae & 1.3 \\
Nabidae & 1.3 \\
Cercopidae & 1.3 \\
Elateridae & 0.5 \\
Calliphoridae & 0.5 \\
Acrididae & 0.5 \\
Tettigoniidae & 0.5 \\
Reduviidae & 0.5 \\
Braconidae & 0.5 \\
Total & 100 \\
\hline
\end{tabular}

entomological findings had been carried out on the crop in this ecology since the introduction of the crop over a century ago. The dominance of Mirperus jaculus and 


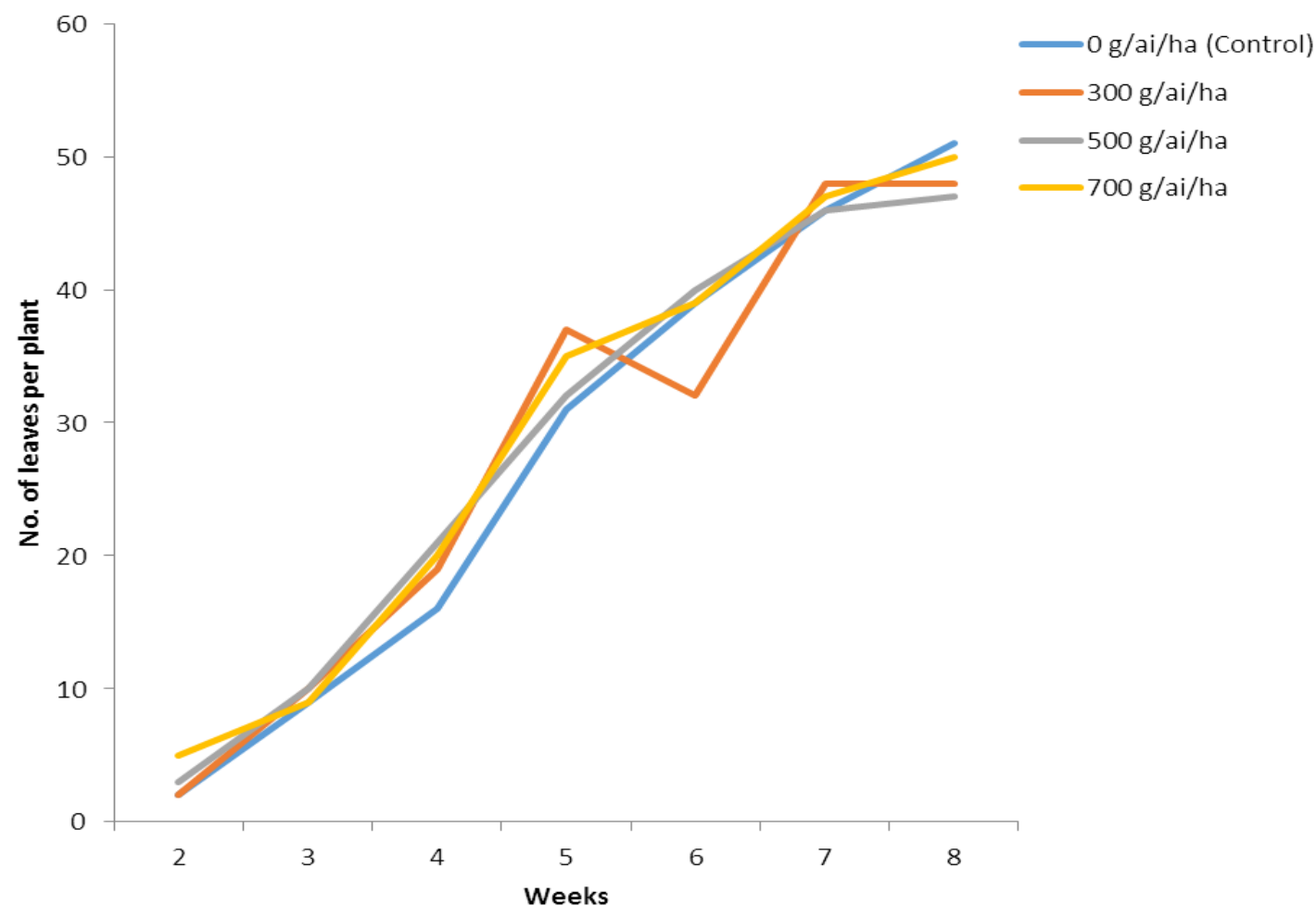

Figure 1. The number of leaves per plant on insecticide treated Vigna radiata plants.

Table 7. Number of days to first flower emergence of insecticide treated green gram plants.

\begin{tabular}{lc}
\hline Dimethoate spray (g a.i./ha) & Number of flowering day \\
\hline Control & 35 \\
300 & 37 \\
500 & 39 \\
700 & 38 \\
\hline
\end{tabular}

$\chi^{2}=0.2349$, df $=3, P=0.9718$.

Table 8. Number of days to $50 \%$ flowering of insecticide treated green gram.

\begin{tabular}{lc}
\hline $\begin{array}{l}\text { Dimethoate spray } \\
\text { (g a.i./ha) }\end{array}$ & $\begin{array}{c}\text { Number of days to } \mathbf{5 0 \%} \\
\text { flowering }\end{array}$ \\
\hline Control & 41 \\
300 & 44 \\
500 & 47 \\
700 & 46 \\
\hline
\end{tabular}

$\chi^{2}=0.47191, \mathrm{df}=3, P=0.925$.

Monolepta nigeriae over other species suggests that there are potential pests of the crop in this sub-northern guinea savanna ecological zone. This corroborates the findings of Ndam (2012) on Mirperus jaculus and Monolepta nigeriae which were found to have associated with soybean (another legume crop) for many years in Benue State within the same ecological zone. Also, Seif et al. (2001) showed that French beans are attacked by a number of different pests which include bean flies, bean flower thrips, aphids, pod borers, bean rust, red spider mites. The severity of infestation of different pests varies depending on the location and season.

\section{Insect abundance}

The lack of variation in the number of insects among the treatments possibly suggests that there is some form of insecticide resistance in the insects in relation to location and season. This is in accordance with the finding of Seif et al. (2001) who showed that the severity of infestation of different pests varies depending on the location and season as farmers control various pests by application of foliar pesticides, especially insecticides in Kenya.

The abundance of insects among $0 \mathrm{~g}$ (control), 300, 500 and $700 \mathrm{~g}$ a.i./h treatments in descending order was 11 , 10,10 and 9 respectively. This suggest that plot with the highest concentration of insecticide $(700 \mathrm{~g}$ a.i $/ \mathrm{h}$ ) tend to repel and influence low insects abundance on $V$. radiata. This is accordance with the finding of Stewart and McClure (2018) who showed that insecticide resistance by insects can be attributed to level of insecticide dosage. Therefore, 


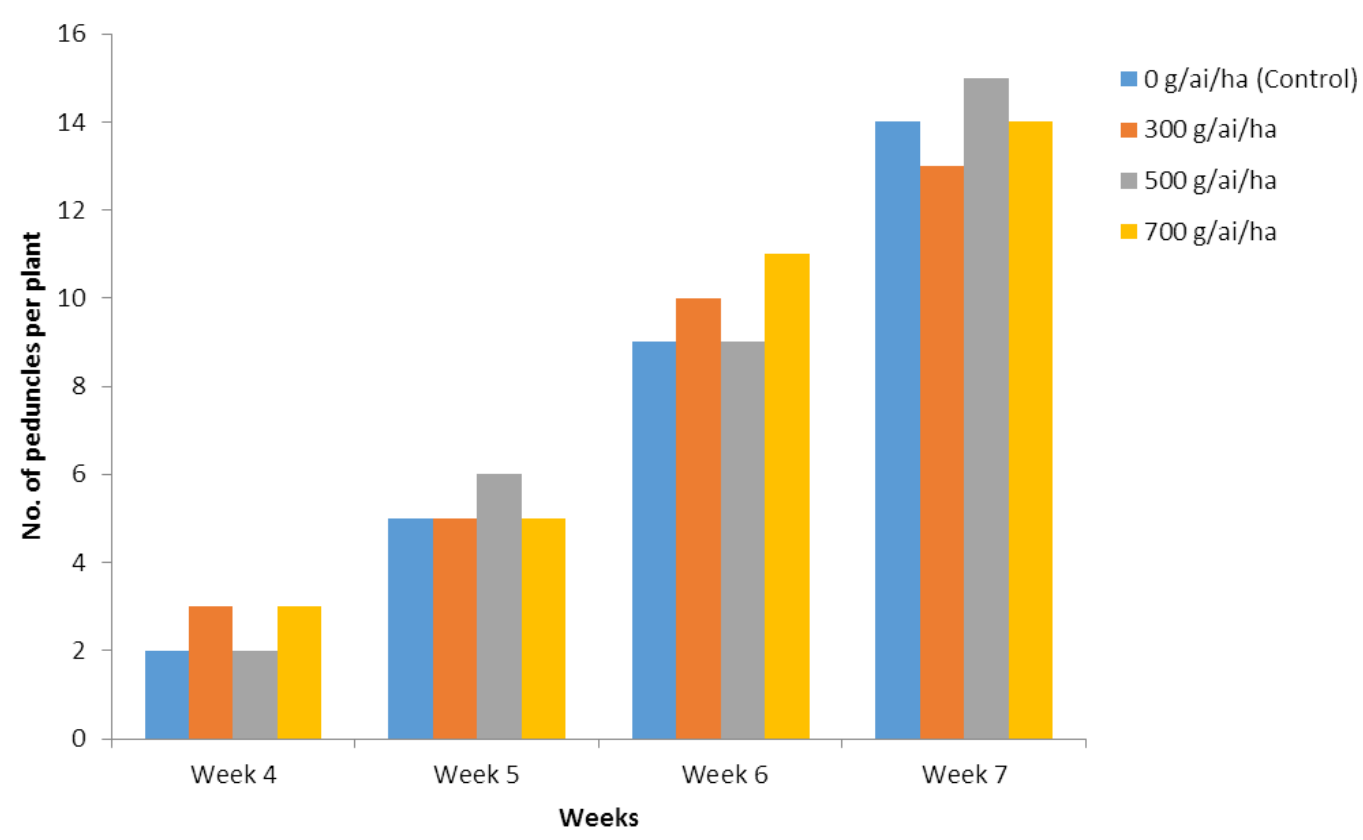

Figure 2. Number of peduncles per plant on insecticide treated Green Gram.

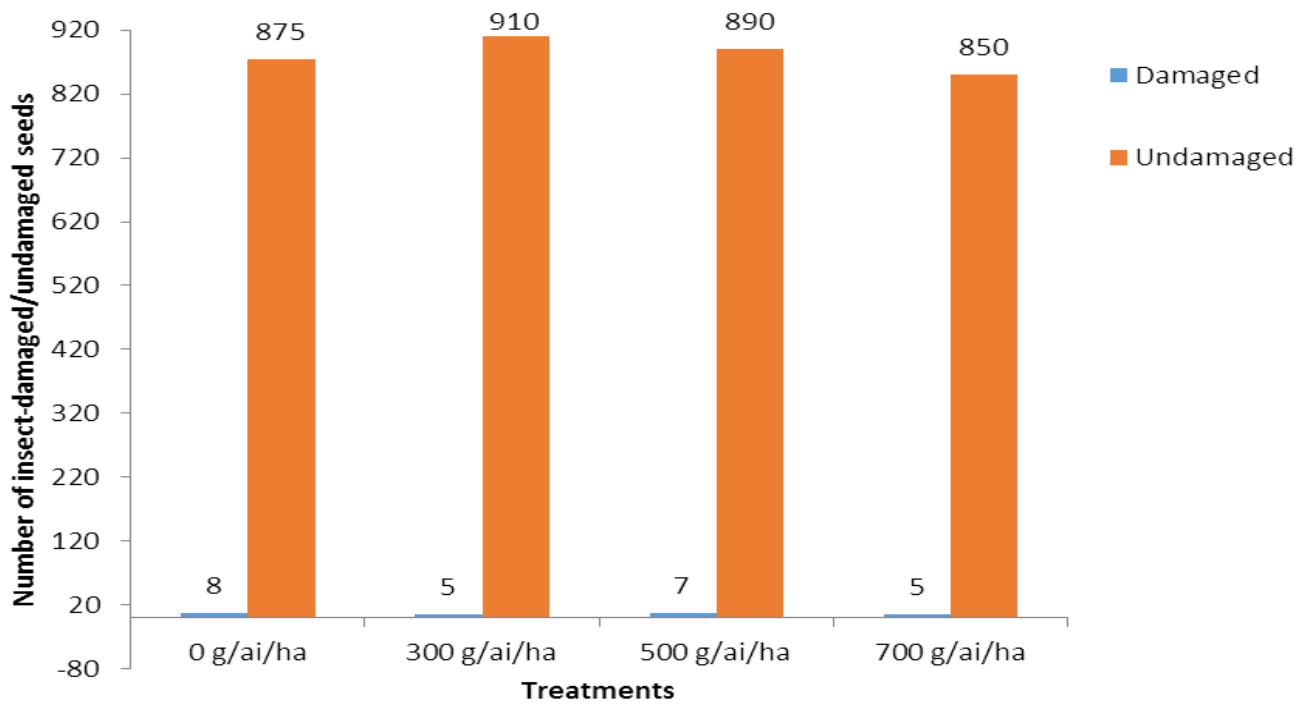

Figure 3. Number of insect-damaged and undamaged seeds from insecticide-treated green gram plants.

increase in insecticide dosage will take care of unsatisfactory control problems of foliar insects.

The total insect count on the crop at the end of the experiment is low. Coleopterous and hemipterous pest species are most abundant. The fact that $54 \%$ of all the insects caught belong to the order coleoptera, gives high hope for natural control. Singh and Taylor (1978) emphasized that predators, especially coccinellid beetles, keep the population of Aphis craccivora under control in the derived savanna ecology in south western Nigeria.

\section{Effect of insecticide application on plant growth parameters}

The number of days to first flower emergence (35 to 39) is not affected by insect infestation as both treated and untreated plots develop at the same place. Similarly, all other growth and yield parameters; number of leaves per plant, number of days to $50 \%$ flowering, number of peduncles per plant and number of pods per plant indicate that green gram could be produced without an insecticide application. 
Table 9. Number of pods per plant on insecticide treated green gram.

\begin{tabular}{lc}
\hline Dimethoate spray (g a.i./ha) & Number of pods per plant \\
\hline Control & 72 \\
300 & 75 \\
500 & 79 \\
700 & 78 \\
\hline
\end{tabular}

$\chi^{2}=0.39474, d f=3, P=0.9413$.

Table 10. Grain yield of insecticide treated green gram.

\begin{tabular}{lc}
\hline Dimethoate spray (g a.i./ha) & Grain yield (t/ha) \\
\hline Control & 0.0017 \\
300 & 0.0015 \\
500 & 0.0015 \\
700 & 0.0016 \\
\hline
\end{tabular}

$\chi^{2}=0, d f=3, P=1$.

\section{Effect of insect damage on yield}

All yield parameters; number of insect-damaged seeds, 100 -seed weight and grain yield are indicative of minimal negative impact of pest species on the crop. While pesticides are meant to provide good protection against pod infestation by pod borers for better seed yield (Mugo, 1989; Muthomi et al., 2007), findings in this experiment are not corroborative.

Some environmental factors that are beyond the control of the researchers may have accounted for lower yields in the dimethoate-treated plots than control, as also observed by Okeyo-Owuor (1978).

\section{Conclusion}

The production of green gram in the Langtang location is not yet threatened by the insect pest species identified and collected. The crop is however exposed to the danger of pest attack as environmental dynamics take their toll. The research further affirms that the area is very suitable for the production of the crop.

\section{Recommendation}

It is therefore recommended that insect surveillance be sustained to monitor insects associated with green gram in this area. This would ameliorate cases of pest emergence among potential pests, unnoticed. It would further help identify possible changes in pests that may be occasioned by changes in consumers' demand for the crop. This recommendation is in line with the emphasis PROTA (2017) has placed on the crop for further research to improve on its productivity.

\section{CONFLICT OF INTEREST}

The authors declare that they have no conflict of interest.

\section{ACKNOWLEDGEMENTS}

The constructive contributions of Prof. (Mrs.) G. S. Mwansat, Dr. (Mrs.) J. A. Yohanna and Dr. H. L. Njila, are highly acknowledged. The authors acknowledge the Curator, Insect Museum of the Ahmadu Bello University, Zaria, for the identification of insect specimens.

\section{REFERENCES}

Adamu, R. S., Dike, M. C., Akpa, A. D. (2001). Insect fauna associated with green gram (Vigna radiata) $\mathrm{R}$. Wilc. In the Northern Guinea Savanna of Nigeria. Journal of Sustainable Agriculture and Environment, 3(2), 331-336.

Anon (2007). Green Gram or Mung Beans (Vigna radiata). ECHO Community, ECHO Development Notes (EDN) | EDN Issue \#93. Available https://www.echocommunity.org/en/resources/65549f80d7b7-4e8d-868c-a60489174038.

Arya, J. (2014). Food is your best medicine. Arya Publications. $328 p$.

Borror, D. J., \& White, R. E. (1970). The Peterson Field Guide Series. A Field Guide to the Insects of America North of Mexico. Houghton Mifflin Company Boston. P. 404.

Castner, J. L. (2000). Photographic Atlas of Entomology and guide to Insect Identification, Feline Press Gainesville U.S.A. Inc. Pp. 74-223.

Central Bureau of Statistics (CBS) (2003). Statistical abstract. Ministry of Planning and National Development, Kenya Government. Pp. 125-130.

Cook, R. J. (1986). Interrelationships of plant health and the sustainability of agriculture, with special reference to plant diseases. American Journal of Alternative Agriculture, 1(1), 19-24.

Davies, J. C., \& Lateef, S. S. (1975). Insect pests of pigeonpea and chickpea in India and prospects for control. In International Workshop on Grain Legumes January 1975, 19-331.

Dike, M. C. (1997). Effect of insect pests on pod and seed yields of bambara, groundnut, Vigna subterranean L. Verde in Nigeria. Int. J. of Pest Management, 43, 1992-1992.

Emmanuel, M. K., Robert, A., Peter, O. I., Pandey, A. K., War, A. R., \& Nair, R. M. (2017). A manual fir mung bean (Greengram) production in Uganda. National Semi-Arid Resources Research Institute (NaSSARRI), National Agricultural Organization (NARO), World Vegetable Centre. 26p.

Kumar, R. (1991). The Fight against Insect Pests, CTA-Khathala. P. 311 Lavabre in EM 1992. Destructive Tropical Cultures. The Technician of Agriculture Tropical. Edited by ACCT-CTAHouse and Larose. P 178.

Lere, P. M. (1996). Rev.Dr. David Obadiah Vrengkat Lot: His life and Church Development on the Jos Plateau. Jos University Press Ltd, Jos. P. 27.

Machocho, A. K., Rugumamu, C. P., Birgen, J. K., Amuka, O., \& Asiimwe, E. (2012). The status of green gram production, pest and disease management in parts of Lake Victoria basin. Ethnobotany and Health Proceedings of the Cluster Workshop, Entebbe, Uganda, 4-7 September 2010. Pp. 81-90. 
Minh, N. P. (2014). Different factors affecting to mung bean (Phaseolus aureus) tofu production. International Journal of Multidisciplinary Research and Development, 1(4), 105-110.

Mogotsi, K. K. (2006). Vigna radiata (L.) R. Wilczek. In: Brink, M., \& Belay, G. (Editors). PROTA 1: Cereals and pulses/Céréales et légumes secs. [CD-Rom]. PROTA, Wageningen, Netherlands.

Muthomi, J. W., Otieno, P. E., Chimining'wa, G. N., Nderitu, J. H. (2007). Effect of chemical pesticide spray on insect pests and yield of food grain legumes. African crop science conference proceedings, 8, 981-986.

Ndam, O. N. (2012). Arthropods associated with soybean and control of noxious species. Lambert academic publishing, Saarbruchen, Germany. p. 124.

Okeyo-Owuor, J. B. (1978). Insect pod borers of pigeon pea (Cajanuscajan (L.) Mills) and their influence on developing pods and final seed yield in Kenya M.Sc. Thesis, University of Nairobi Kenya, Pp 150.

Paulson, S. G. (2005). Handbook to the Construction and Use of Insect Collection and Rearing Devices: A guide for teachers with suggested classroom applications. P. 121

PROTA (2007). Cereals and pulses of Tropical Africa (Bosch C. H., \& Borus D. J.Eds.). Conclusions and recommendations based on PROTA 1: 'Cereals and pulses'. PROTA Foundation, Wageningen, Netherlands. p. 96.

Purseglove, J. W. (2003). Tropical Crops. Longman, London.

Raman, R. (2018). 10 Impressive Health Benefits of Mung Beans. Nutrition newsletter. Available at https://www.healthline.com/nutrition/mung-beans\#section1.

Rao, M. R., Singh, M. P., Day, R. (2000). Insect pest problem in tropical agro-forestry systems: Contributory factors and strategies for management. Agro-forestrySystems. 50, 243277.

Rao, S. M., Reddy, D. K., \& Singh, T. V. K. (2004). Impact of intercropping on the incidence of Maruca vitrata (Geyer)and Helicoverpa armigers (Hubner)and their predators on pigeon pea during rainy and post rainy seasons. Shashpa, 11(1), 67-70.
Saxena, H. P. (1978). Pests of grain legumes and their control in India. Indian Agricultural Research Institute, New Delhi, India. Pp. 15-23.

Schroth, G., Krauss, U., Gasparotto, L., Duarte, J. A., Vohland, K. (2000). Pests and diseases in Agro-forestry systems of the humid tropics. Agro-forestry systems. 50,199-241.

Seif, A., Varela, A. M., Michalik, S., \& Lohr, B. (2001). A Guide to IPM in French beans production with emphasis on Kenya. $p$. 99.

Shattuck, S. O. (2000). Australian ants, their biology and identification. CSIRO Publishing. p. 226.

Singh, S. R., \& Taylor, A. T. (1978). Pests of grain legumes and their control in Nigeria. Pests of Grain Legumes: Ecology and Control. Academic Press London LTD 24/28 Oval Road. New York. San Francisco. Pp. 99-111.

Skaife, S. H., Ledger, J., \& Bannister, A. (1979). African Insect Strulk Publishers. p. 354.

Stewart, S., \& McClure, A. (2018). 2018 Insect Control Recommendations for Field Crops: Cotton, Soybean, Field Corn, Sorghum, Wheat and Pasture. p. 54.

Tang, D., Dong, Y., Ren, H., Li, L. and He, C. (2014). A review of phytochemistry, metabolite changes, and medicinal uses of the common food mung bean and its sprouts (Vigna radiata). Chemistry Central Journal, 8(4), 1-9.

Utama, H. (2018). Evaluation of Adaptability of Mung Bean Varieties in Moisture Stress of Eastern Harerghe Zone. Agricultural Research and Technology, 13(2), 1-4.

United Republic of Tanzania (URT) (2003). Mwanza Region Socio-Economic Profile. National Bureau of Statistics and Mwanza Regional Commissioners Office. Kenya. 